\title{
Simulation of transport and persistence of carbamate aldicarb in soil columns
}

\author{
Simulação do transporte e persistência do carbamato aldicarbe em colunas de solo \\ Simulación de transporte y persistencia de carbamato de aldicarb en columnas de suelo
}

Received: 04/08/2021 | Reviewed: 04/16/2021 | Accept: 04/16/2021 | Published: 05/01/2021

\author{
José Fábio França Orlanda \\ ORCID: https://orcid.org/0000-0002-6402-6192 \\ Maranhão Tocantina Region State University Brazil \\ E-mail: fabio.franca@uemaul.edu.br \\ Flávia Emília Jacinto \\ ORCID: https://orcid.org/0000-0001-9971-7818 \\ Viçosa Federal University, Brazil \\ E-mail: flaem_qui@yahoo.com.br \\ Antônio Augusto Neves \\ ORCID: https://orcid.org/0000-0002-2152-6736 \\ Viçosa Federal University, Brazil \\ E-mail: aneves@ufv.br \\ Maria Eliana Lopes Ribeiro de Queiroz \\ ORCID: https://orcid.org/0000-0003-4717-9223 \\ Viçosa Federal University, Brazil \\ E-mail: aneves@ufv.br
}

\begin{abstract}
This study evaluated the mobility and persistence of aldicarb and its degradation products in red-yellow oxisol (LVA) using soil columns, after the application of Temik 150. Leaching experiments were performed using polyvinyl chloride (PVC) columns filled with soil contaminated with aldicarb and rain simulation of $6.05 \mathrm{~mm} \mathrm{day}^{-1}$, at 10 day intervals, for 90 days. Aldicarb, aldicarb sulfoxide and aldicarb sulfone residues were extracted from soil (solid-liquid) and percolated water (liquid-liquid) samples with quantification by CG-FID. The results showed that aldicarb was rapidly oxidized to aldicarb sulfoxide and aldicarb sulfone in 10 days after the application. Aldicarb sulfoxide percolated through $15 \mathrm{~cm}$ of the soil column and could not be detected in the soil after 40 days incubation. From the 60 days since application, residues were no longer detected in the samples of percolated water and soil fractions, indicating rapid degradation and low potential for groundwater contamination.
\end{abstract}

Keywords: Aldicarb; Degradation products; Pollution; Environment.

\section{Resumo}

Este estudo avaliou a mobilidade e persistência do aldicarbe e seus produtos de degradação em latossolo vermelhoamarelo (LVA) utilizando colunas de solo, após a aplicação de Temik 150. Os experimentos de transporte foram realizados empregando colunas de policloreto de vinila (PVC) preenchidas com solo contaminado com aldicarbe e simulação de chuva de $6,05 \mathrm{~mm} \mathrm{dia}^{-1}$, em intervalos de 10 dias, durante 90 dias. Os resíduos de aldicarbe, aldicarbe sulfóxido e aldicarbe sulfona foram extraídos das amostras de solo (sólido-líquido) e água percolada (líquido-líquido) com quantificação por CG-FID. Os resultados mostraram que o aldicarbe foi rapidamente oxidado a sulfóxido de aldicarbe e sulfona de aldicarbe em 10 dias após a aplicação. O sulfóxido de aldicarbe percolou $15 \mathrm{~cm}$ da coluna de solo e não foi detectado no solo após 40 dias de incubação. A partir dos 60 dias da aplicação, não foram mais detectados resíduos nas amostras de água percolada e nas frações do solo, indicando rápida degradação e baixo potencial de contaminação do lençol freático.

Palavras-chave: Aldicarbe; Produtos de degradação; Poluição; Meio ambiente.

\section{Resumen}

Este estudio evaluó la movilidad y persistencia del aldicarb y sus productos de degradación en latosol rojo-amarillo (LVA) utilizando columnas de suelo, luego de la aplicación de Temik 150. Los experimentos de transporte se llevaron a cabo utilizando columnas rellenas de cloruro de polivinilo (PVC) con suelo contaminado con aldicarb y simulación de lluvia de 6,05 mm día ${ }^{-1}$, a intervalos de 10 días, durante 90 días. Los residuos de aldicarb, aldicarb sulfóxido y aldicarb sulfona se extrajeron de muestras de suelo (sólido-líquido) y agua percolada (líquido-líquido) con cuantificación por CG-FID. Los resultados mostraron que el aldicarb se oxidaba rápidamente a sulfóxido de aldicarb y sulfona de aldicarb en 10 días después de la aplicación. El sulfóxido de aldicarbo se filtró a $15 \mathrm{~cm}$ de la columna del suelo y no se detectó en el suelo después de 40 días de incubación. Después de 60 días de aplicación, ya no se detectaron residuos en las muestras de agua filtrada y en las fracciones del suelo, lo que indica una rápida degradación y un bajo potencial de contaminación del nivel freático. 
Palabras clave: Aldicarb; Productos de degradación; Polución; Medio ambiente.

\section{Introduction}

Aldicarb (2-methyl-2-(methylthio)propionaldehyde-O-methylcarbamoyloxime) is an insecticide, acaricide and systemic nematicide, derived to carbamic acid (Figure 1), registered in Brazil for the reduction of the miner, Leucoptera coffeella (Guérin-Méneville) (Lepidoptera: Lyonetiidae), considered the main coffee pest in some regions of the state of Minas Gerais, Brazil (Lewis et al., 2016; Xavier et al., 2007; Rigitano et al., 1993; Piffer \& Rigitano, 1991).

Figure 1. Structural formula of aldicarbe.<smiles>CNC(=O)O/N=C/C(C)(C)S</smiles>

Source: Agrofit (2021).

Aldicarb when pure as white solid, characteristic odor, $190.3 \mathrm{~g} \mathrm{moL}^{-1}$ molecular mass, $150{ }^{\circ} \mathrm{C}$ boiling point, highly toxic (Toxicological Class I), low water solubility and commercialized as Temik in granular formulas varying from 5 to $15 \%$ (Agrofit, 2021; Inchem, 2018; Piffer \& Rigitano, 1991).

The carbamate insecticides exhibit high acute toxicity because they inhibit the activity of biological enzymes, such as cholinesterase (Kim et al., 2017; Morais et al., 2013; Santaladchaiyakit et al., 2012; Tankiewicz et al., 2010), with the possibility of their residues being found in soil, food, crops, groundwater and surface water (Lewis et al., 2016; Goulart et al., 2010).

Agrochemical monitoring in environmental matrices has become essential to reduce environmental impact, and can be carried out through studies of the mechanisms in transport of these molecules in profile the soil (Refatti et al., 2017; Khan et al., 2016; Barizon et al., 2006).

The percolation column method has been employee in studies that aim to evaluate pesticide movement in soils. This method consists in percolation of pesticides with a known concentration in polyvinyl chloride (PVC) columns filled with soil up to the exit at the base of the column, that allows evaluation of the leaching potential, redistribution and helps in the understanding of the possible chemical and physical interactions involved in the movement (Kalbe et al., 2014; Garcia et al., 2012; Kalbe et al., 2007; Brusseau, 1998; Baskaran et al., 1996).

In this way, the aim of this work was to investigate the mobility potential, degradation and persistence of aldicarb in columns of red-yellow oxisol from an area with coffee cultivation.

\section{Methodology}

\subsection{Chemicals and solvents}

The pesticides aldicarb (99.7\%), aldicarb sulfoxide (99\%) and aldicarb sulfone (99\%) were obtained from Sigma Aldrich, used as an internal standard in the GC analysis. The structures of the studied pesticides are shown in Table 1. Commercial aldicarb formulation (Temik 150 Bayer S/A - Brazil 48SC, 48\% w/v) was acquired from a local store. 
Table 1. Chemical structure of the aldicarb and products of degradation under study.

\begin{tabular}{c|l|c|c}
\hline \multicolumn{1}{c|}{ Pesticides } & \multicolumn{1}{|c|}{ IUPAC Chemical name } & Class & \multicolumn{2}{c}{ Structure } \\
\hline Aldicarb & $\begin{array}{l}\text { O-(Methylcarbamoyl)-2-methyl-2- } \\
\text { (methylthio)propionaldehyd-oxime }\end{array}$ & Carbamate & Carbamate \\
\hline Aldicarb sulfone & $\begin{array}{l}\text { [(E)-(2-methyl-2- } \\
\text { methylsulfonylpropylidene)amino] } \\
\text { N-methylcarbamate }\end{array}$ & $\begin{array}{l}\text { Carbamate } \\
\text { Aldicarb sulfoxide } \\
\text { Nethylsulfinylpropylidene)amino] }\end{array}$ & \\
\hline
\end{tabular}

Source: Agrofit (2021).

The solvents acetone (chromatographic grade - Vetec), chloroform, dichloromethane and ethyl acetate (analytical grade - Vetec) were employed as solvent extractors. Anhydrous sodium sulfate (Vetec) was used to dry the extracts.

\subsection{Soil}

The soil used for the experiments was collected from a commercial coffee plantation located on rural properties in Federal University of Viçosa (Viçosa, Minas Gerais, Brazil) with no history of annual aldicarb application (Figure 2).

Figure 2. Location of the UFV Campus, the municipality of Viçosa and the Minas Gerais State.

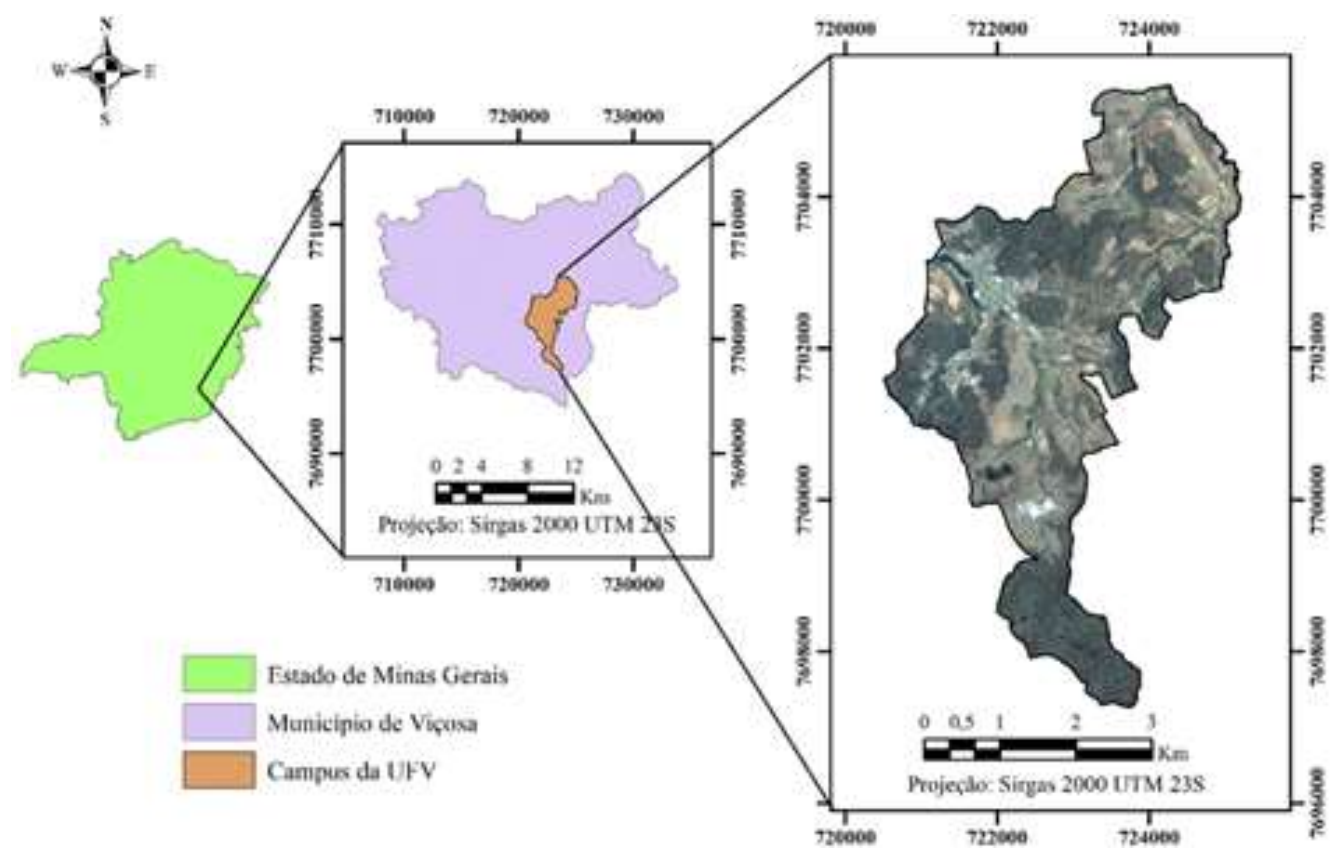

Source: Almeida et al. (2016).

Soil red-yellow oxisol samples were collected from 0-5 and 5-20 cm depth, air-dried, sieved (2 mm) and stowed in plastic bags. Textural, chemical and mineralogical properties were $\mathrm{pH} 6.1,7.98 \mathrm{cmol}_{\mathrm{c}} \mathrm{dm}^{-3}$ effective ion exchange ability, $4.73 \%$ organic matter, $41 \%$ clay, $23 \%$ silt, $46 \%$ sand and presence in clay fraction of kaolinite, gibbsite and goethite. 


\subsection{Leaching experiments}

Leaching experiments were performed using 40 polyvinyl chloride (PVC) columns, built with three $5 \mathrm{~cm}$ high rings and $10 \mathrm{~cm}$ diameter packed with the yellow oxisol soil (Figure 3), according Faria et al. (2016) and Matragolo (1999).

Figure 3. Percolation column to evaluation the mobility.

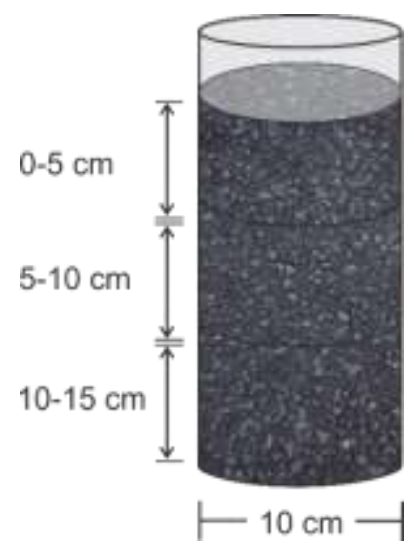

Source: Authors.

The insecticide aldicarb were applied to the top of the 30 soil columns, using $0.2 \mathrm{~g}$ the product Temik 150 and ten were left without the active principle (witness experiment). The rain simulation was carried out every ten days, with water volume of $475.0 \mathrm{~mL}$, corresponding to $6.05 \mathrm{~mm}$ per day.

After the rainfall simulation, four columns (one witness and three replicates) were separated lengthwise in fractions of $5 \mathrm{~cm}$ and volume of percolated water collected, for extraction and analysis.

\subsection{Sample extraction}

Aldicarb, aldicarb sulfoxide and aldicarb sulfone were extracted from soil samples using solid-liquid extraction (SLE) and percolated water by liquid-liquid (LLE). For insecticide extraction, $10 \mathrm{~g}$ of soil and $15.0 \mathrm{~mL}$ of chloroform (three times) were added to a $100 \mathrm{~mL}$ glass vial, under stirring for 10 minutes at $120 \mathrm{rpm}$. After the separation of phases, organic fraction was transferred through a filter containing $2.0 \mathrm{~g}$ anhydrous sodium sulfate and concentrated in a rotary evaporator at $50{ }^{\circ} \mathrm{C}$ under reduced pressure until dried. The residues were re-dissolved in $10 \mathrm{~mL}$ of chloroform for analysis chromatographic (Faria et al., 2016).

Similarly, a sample of $10 \mathrm{~mL}$ percolated water through leaching columns was extracted three times using $10 \mathrm{~mL}$ chloroform (LLE), filtered through anhydrous sodium sulfate and evaporated to about $1 \mathrm{~mL}$ in a rotary evaporator. Then, the extracted volume was completed to $10 \mathrm{~mL}$ with chloroform and analyzed by GC-FID.

\subsection{Pesticide analysis}

A GC Shimadzu model GC-17A, equipped with a flame ionization detector (FID) and a fused silica capillary column

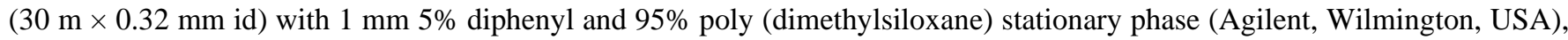
and having nitrogen as carrier gas $\left(1.2 \mathrm{~mL} \mathrm{~min}^{-1}\right)$ was used at the following conditions: $80{ }^{\circ} \mathrm{C}$, with a heating ramp of $10{ }^{\circ} \mathrm{C} \mathrm{min}-1122{ }^{\circ} \mathrm{C}$, held for $5 \mathrm{~min}$. The injector and detector temperatures were $250{ }^{\circ} \mathrm{C}$ and $300{ }^{\circ} \mathrm{C}$, respectively. A volume of $1 \mathrm{~mL}$ was injected in split mode at the split ratio of 1:5. 
The following parameters were used to validate the method: selectivity, linearity of the response, accuracy (recovery percentage), precision (coefficient of variation of the results obtained in the replicates, $\mathrm{n}=3$ ), limits of detection (LD) and quantification (LQ) (Palma et al, 2014).

\section{Results and Discussion}

\subsection{Chromatographic analysis}

Figure 4 shows a chromatogram of the standard solution having the carbamates in study at concentration of $75.0 \mu \mathrm{g} \mathrm{mL} \mathrm{m}^{-1}$. Peaks with retention times $\left(\mathrm{t}_{\mathrm{R}}\right)$ equal to $6.92,11.09$ and $11.61 \mathrm{~min}$ correspond to aldicarb, aldicarb sulfone and aldicarb sulfoxide, respectively.

Figure 4. Chromatogram of a solution containing the carbamates studied, in chloroform at concentration of $75 \mu \mathrm{gL} \mathrm{L}^{-1}$, where: $1\left(t_{R}=6.92 \mathrm{~min}\right)$ is aldicarb; $2\left(t_{R}=11.09 \mathrm{~min}\right)$ is aldicarb sulfone and $3\left(t_{R}=11.61 \mathrm{~min}\right)$ is aldicarb sulfoxide.

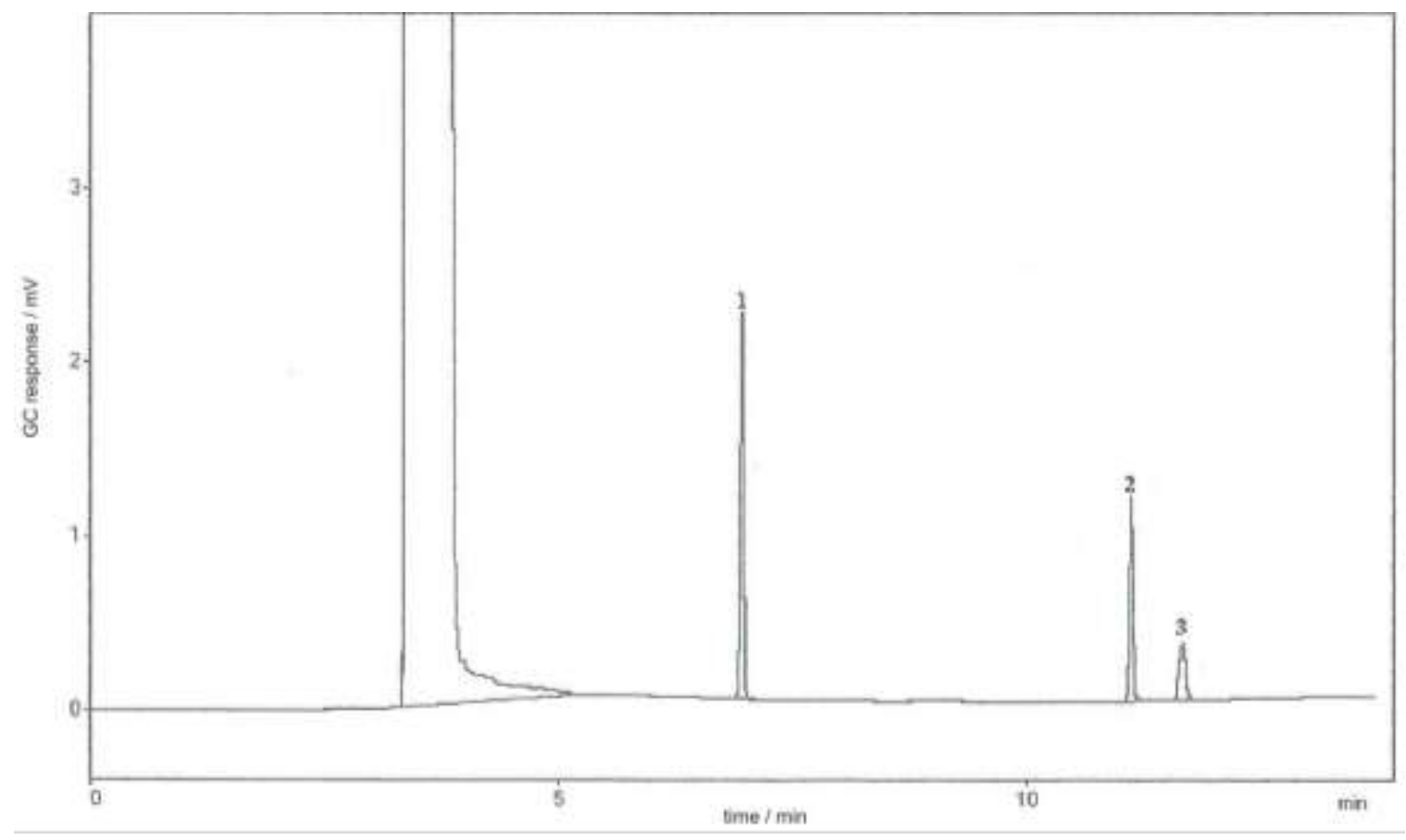

Source: Research Data.

\subsection{Validation of the analytical method}

The parameters of the analytical validation and recoveries for all the carbamates in soil and water are presented in Table 2. 
Research, Society and Development, v. 10, n. 5, e13710514824, 2021

(CC BY 4.0) | ISSN 2525-3409 | DOI: http://dx.doi.org/10.33448/rsd-v10i5.14824

Table 2. Validation parameters and percentage recoveries of the method for the pesticides studied.

\begin{tabular}{|c|c|c|c|c|c|c|c|c|}
\hline \multirow{4}{*}{ Compounds } & \multicolumn{8}{|c|}{ Validation Parameters } \\
\hline & \multicolumn{2}{|l|}{ Linearity } & \multirow{3}{*}{$\begin{array}{l}\text { LOD }^{\mathrm{a}} \\
\left(\mu \mathrm{g} \mathrm{mL} \mathrm{L}^{-1}\right)\end{array}$} & \multirow{3}{*}{$\begin{array}{l}\mathrm{LOQ}^{\mathrm{b}} \\
\left(\mu \mathrm{g} \mathrm{mL}^{-1}\right)\end{array}$} & \multicolumn{4}{|c|}{ Recoveries \pm RSD (\%) } \\
\hline & \multirow{2}{*}{$\begin{array}{l}\text { Linear working range } \\
\qquad\left(\mu \mathrm{g} \mathrm{mL}^{-1}\right)\end{array}$} & \multirow[t]{2}{*}{$\mathrm{r}$} & & & \multicolumn{2}{|c|}{ Spiked water sample ${ }^{c}$} & \multicolumn{2}{|c|}{ Spiked soil sample $^{\mathrm{d}}$} \\
\hline & & & & & $5.00 \mu \mathrm{g} \mathrm{mL}^{-1}$ & $50.00 \mu \mathrm{g} \mathrm{mL}^{-1}$ & $5.00 \mu \mathrm{g} \mathrm{mL}^{-1}$ & $50.00 \mu \mathrm{g} \mathrm{mL}^{-1}$ \\
\hline Aldicarb & 0.5 to 100.00 & 0.999 & 0,5 & 0,5 & $82.8 \pm 0.5$ & $89.7 \pm 0.3$ & $86.00 \pm 0.6$ & $88.10 \pm 0.2$ \\
\hline Aldicarb Sulfoxide & 0.5 to 100.00 & 0.998 & 0,5 & 0,5 & $60.3 \pm 0.4$ & $51.1 \pm 0.3$ & $89.00 \pm 0.2$ & $86.70 \pm 0.8$ \\
\hline Aldicarb Sulfone & 0.5 to 100.00 & 0.999 & 0,5 & 0,5 & $84.4 \pm 0.9$ & $91.2 \pm 0.7$ & $82.00 \pm 0.2$ & $81.40 \pm 0.3$ \\
\hline
\end{tabular}

aLOD: limit of detection; 'LOQ: limit of quantification; ${ }^{\mathrm{c}}$ Extracted with chloroform. ${ }^{\mathrm{d}}$ Extracted with chloroform. Source: Research Data. 
All carbamates showed linearity in the concentration range of 0.5 to $50.00 \mu \mathrm{g} \mathrm{mL}^{-1}$, with linear regression correlation coefficients between peak areas and spiking concentrations above $0.99, \mathrm{LD}<0.17 \mu \mathrm{g} \mathrm{mL}-1$ and LOQ $<0.50 \mu \mathrm{gL} \mathrm{mL}^{-1}$ (Table 2). The values of the correlation coefficients (r) agree with the values recommended by ANVISA and the Instituto Nacional de Metrologia, Normalização e Qualidade Industrial (INMETRO). ANVISA recommends a correlation coefficient of at least 0.99 and INMETRO suggests values above 0.90 .

The results from the optimization of the extraction procedure in water and soil samples are presented in Table 2. The solvent which presented most efficiency in recovery was chloroform for water and soil samples fortified with two concentration levels of aldicarb and its degradation products $\left(5.0\right.$ and $\left.50.0 \mu \mathrm{g} \mathrm{mL}^{-1}\right)$, performed at three replicates for each level.

As can be seen in Table 2, recoveries for all the compounds resulted in values ranging from 51.1 to $91.2 \%$ at the two levels of concentrations assessed, with excellent accuracy and RSD values lower than 1.0\%. These recovery percentages are in accordance with acceptable recovery values for pesticide residue analysis, ranging from 70 to $120 \%$, on average, with accuracy expressed in terms of $\mathrm{CV}<20 \%$ (Nunes \& Ribeiro, 1999; Blumhorst, 1996). The evaluated parameters indicate the good performance of the analytical method proposed for the analyses of carbamates in water and soil.

\subsection{Leaching of pesticides}

The vertical mobility percentages of aldicarb, aldicarb sulfone and aldicarb sulfoxide during 90 days in yellow oxisol soil (LVA), using the column leaching experiments, are presented in Figure 5 at the depths of $0-5,5-10,10-15 \mathrm{~cm}$ and percolation water $(>15 \mathrm{~cm})$, respectively.

Figure 5. Percentage of leaching of aldicarb, aldicarb sulfone and aldicarb sulfóxide for 90 days, at different depths.

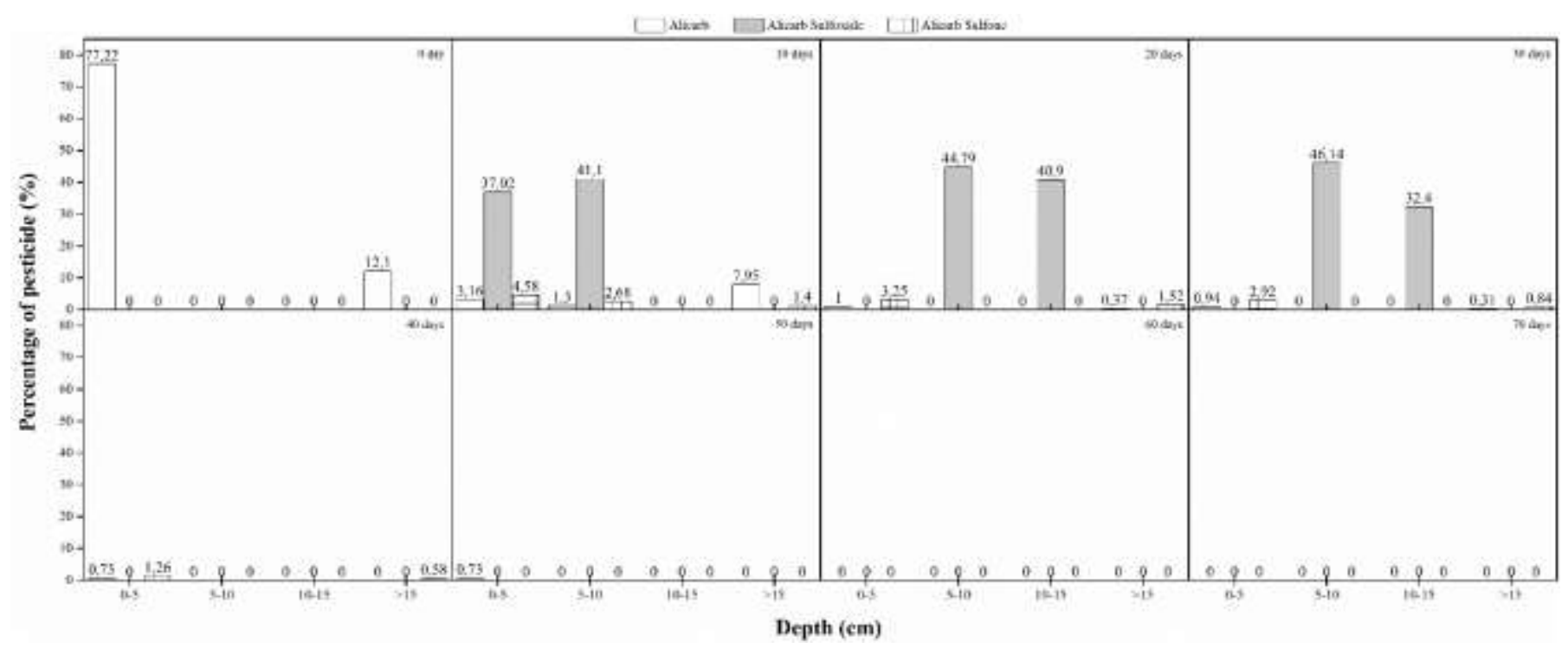

Source: Research Data.

As observed in Fig. 5, the total percentage of aldicarb obtained in the first rain simulation immediately after carbamate application, showed very heterogeneous distribution over the soil column, with $77.22 \%$ recovery at $0-5 \mathrm{~cm}$ depth and $12.1 \%$ at percolated water $(>15 \mathrm{~cm}$ ), evidencing a rapid movement in the soil profile, in a non-equilibrium condition, 
probably due to insufficient time to complete the interaction of residues with soil colloids (Lightfoot et al., 1987; Leistra et al., 1976).

According to Rao et al. (1982), the processes of transportation and movement of pesticides in the soil depend on their retention in the solid, organic and mineral phases (Arantes et al., 2012). The adsorption of agrochemicals to the soil is important, mainly because it is directly related to the availability processes in the compound activity, degradation by soil microorganisms and, conversely, the possibility of leaching and contamination of surface and groundwater (Silva et al., 2010; Wauchope et al., 2002).

Ten days after application, about 3.16,1.3 and 7.95\% aldicarb of the initial amount applied was detected at the depths of 0-5 and5-10 cm and percolated water (> $15 \mathrm{~cm}$ ), respectively. In this period the products of degradation aldicarb sulfone and aldicarb sulfoxide were detected with downward movement to $10 \mathrm{~cm}$ depth, presenting total percentages of 7.27 and $78.10 \%$, as shown in Fig. 5. These results are consistent with the soil aldicarb degradation pathway suggested by Piffer (1989) and Wilkinson et al. (1985), as shown in Figure 6.

Figure 6. Aldicarb degradation route in the soil.<smiles>CC(=NN(C)C)C(C)(C)C</smiles>

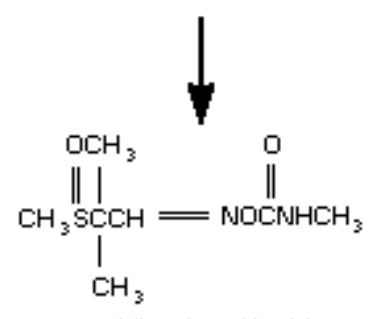
aldicarb sulfoxide

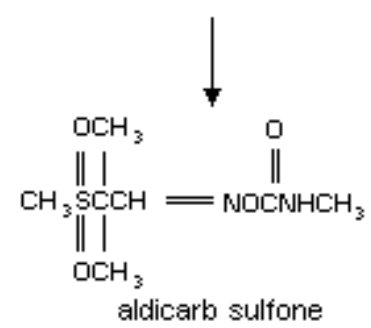

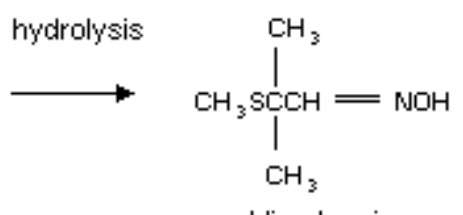

$$
\text { aldicarb oxime }
$$<smiles>CCCCC(C)(C)C(=N)O</smiles>

aldicarb oxime sulfoxide

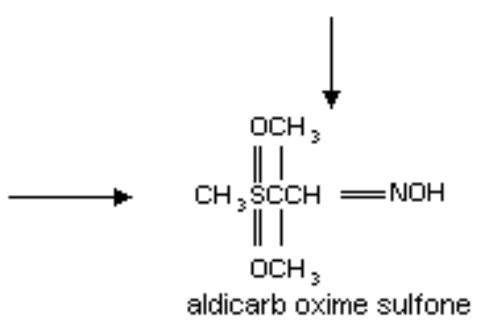<smiles>C[As](C)(C)C#N</smiles>

aldicarb nitrile

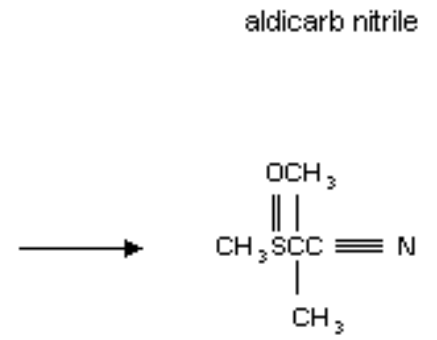

aldicarb nitrile sulfoxide

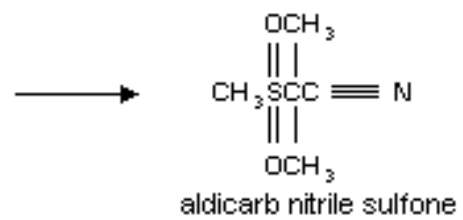

Source: Piffer (1989) and Wilkinson et al. (1985).

Twenty days after aldicarb application, there was a decrease in the amount of aldicarb and sulfone of aldicarb in the columns (1.0 and 3.25\%). During this period, aldicarb sulfoxide leaching was verified from the 5-10 and 10-15 cm deep layers and presence of aldicarb and aldicarb sulfone in percolated water, indicating that these products reached the last layer of the investigated soil column (Figure 5).

The rapid mobility of aldicarb and degradation products may be related to the textural characteristics of soil under study which presented low levels of clay (46\%), organic matter (4.7\%) and cation exchange capacity $\left(7.98 \mathrm{cmol} \mathrm{dm}^{-3}\right)$ promoting the reduction of particle aggregation capacity and pesticide adsorption, making the soil susceptible to leaching process (Reatto \& Martins, 2005). 
According to Castro et al. (2005), this high leaching potential has been attributed to the rapid oxidation of aldicarb to sulfoxide and sulfone of aldicarb in soils, and to the low sorption of these in soil organic matter, due to its low lipophilicity ( $\log$ Kow values of $1.08,-0.69$ and -0.57 for aldicarb, aldicarb sulfoxide and aldicarb sulfone, respectively).

Leistra et al. (1976) reported similar results in which aldicarb sulfoxide and sulfone were poorly adsorbed by organic matter, thus presenting relatively high mobility in soils.

From day 30, aldicarb sulfoxide was detected in the layers of 5 to 10 and 10 to $15 \mathrm{~cm}$, around $78.50 \%$, but it was not found in any of the soil fractions after the 40th day. This effect is attributed to low stability of aldicarb sulfoxide in the soil, since the compound is rapidly degraded into corresponding oximes and nitriles. At 40 days after application, a fall in the total percentage of residues detected in the columns from 83.6 to $2.5 \%$ was observed. But small amounts of aldicarb and sulfone of aldicabe were detected only in the first five centimeters of the column. In addition, aldicarb disappeared in percolated water and only aldicarb sulfone was detected in this rainfall simulation. Fifty days after application, only a small amount of aldicarb was present in the 0 to $5 \mathrm{~cm}$ fraction. After 60 days, the amounts of aldicarb, aldicarb sulfoxide and aldicarb sulfone residues found in the columns were extremely low, probably due to the formation of non-carbamate compounds.

According to Piffer and Rigitano (1991), aldicarb leaching of degradation columns under normal growing conditions is probably less than that observed in laboratory simulations, since the plants absorb some of the residues and the removal of water from the soil by reduce the amount of water percolating in the soil profile. On the other hand, the transport of residues beyond $50 \mathrm{~cm}$ may be advantageous in the case of cicada nymphs that attack the coffee tree roots, which can be found at depths exceeding $50 \mathrm{~cm}$.

Although the present study did not quantify residue transport at depths greater than $15 \mathrm{~cm}$, it was evident that an appreciable proportion of the applied amount of aldicarb was transported beyond this depth. In the case of the soil under study, the water table is located several meters deep and, therefore, it is unlikely that significant amounts of aldicarb residues and degradation products will reach the groundwater.

\section{Conclusion}

In the present study, a percolation system was used that can assess aldicarb mobility in soil red-yellow latosol. Aldicarb was rapidly oxidized to aldicarb sulfoxide and aldicarbe sulfone 10 days after applying the Temik 150. Aldicarb and products of degradation 90 days after application were not detected in any of the soil fractions and percolated water analyzed. Aldicarb leached up to $15 \mathrm{~cm}$ deep in the column percolation, indicating a smaller potential risk of surface water contamination.

\section{Acknowledgments}

The authors would like to thank Viçosa Federal University (UFV) for providing the necessary structure and Coordination of Improvement of Higher Level Personnel (CAPES) for financial support to execute this project.

\section{References}

ANVISA. (2003). Guia para validação de métodos analíticos e bioanalíticos. Agência Nacional de Vigilância Sanitária (ANVISA). Agência Nacional de Vigilância Sanitária do Brasil; 2003. Resolução - RE nº 899, de 29 de maio de 2003.

AGROFIT. Sistema de Agrotóxicos Fitossanitários. http://agrofit.agricultura.gov.br/agrofit_cons/principal_agrofit_cons.

Almeida, L. T., Monteiro, L. I. B., Silva, F. B., \& Corrêdo, L. de. (2016). Locação de corredores ecológicos e área de preservação permanente na Universidade Federal de Viçosa. Nativa, 4(6), 412-418. 
Research, Society and Development, v. 10, n. 5, e13710514824, 2021

(CC BY 4.0) | ISSN 2525-3409 | DOI: http://dx.doi.org/10.33448/rsd-v10i5.14824

Andréa, M. M., \& Luchini, L. C. (2002). Comportamento de pesticidas em solos brasileiros: a experiência do Instituto Biológico/SP. Boletim da Sociedade Brasileira de Ciência do Solo, 27(2), 22-24.

Arantes, S. A. do. C. M., de Lima, J. M., Lima, L. A., de Jesus, E. A., Julião, L. G. F., \& Arantes, K. R. (2012). Influência do sistema de manejo na retenção e mobilidade da atrazina em amostras de solos. Revista Brasileira de Ciências Agrárias, 7(1), 167-173.

Barizon, R. R. M., Lavorenti, A., Regitano, J. B., Prata, F., \& Tornisielo, L. (2006). Simulação do transporte e da sorção de imazaquin em colunas de solo. Revista Brasileira de Ciência do Solo, 30, 615-623.

Baskaran, S, Bolan, N. S., Rahman A., \& Tillman, R. W. (1996). Non-equilibrium sorption during the movement of pesticides in soils. Journal of Pest Science, 46, 333-343.

Blumhorst, M. R. (1996). Experimental paramenteres used to study pesticide degradation in soil. Weed Technology, 10(1), 169-173.

Brusseau, M. L. (1998). Impact of chemical and biochemical reactions on transport of environmental pollutants in porous media. In: Huang PM, editors. Soil chemistry and ecosystem health. Madison: Soil Science Society of America. 173-189.

Castro, N. R. A., Rigitano, R. L. de. O., de Lima, J. M., \& Bastos, C. J. (2005). Lixiviação de aldicarbe em macrolisímetros de dois Latossolos. Pesquisa Agropecuária Brasileira, 40(8), 803-810.

Faria, A. M., Noronha, L. M. S., Dardengo, R. P., Neves, A. A., \& de Queiroz, M. E. L. R. (2016). Mobility and degradation of disulfoton in coffee culture soil. Environmental Technology \& Innovation, 5, 1-9.

Garcia, D. de. B., Alves, S. N. R., Cason, J. B., \& Christoffolet, P. J. (2012). Lixiviação de diuron, hexazinone e sulfometuron-methyl em formulação comercial e isoladamente em dois solos contrastantes. Revista Brasileira de Herbicidas, 11(2), 222-230.

Goulart, S. M., Alves, R. D., Neves, A. A., de Queiroz, J. H., de Assis, T. C., \& Queiroz, M. E. L. R. de. (2010). Optimization and validation of liquid-liquid extraction with low temperature partitioning for determination of carbamates in water. Analytica Chimica Acta, 671, 41-47.

INCHEM. Chemical Safety Information from Intergovernmental Organizations. http:// www.inchem.org.

INMETRO. (2003). Orientações sobre validacão de métodos de ensaios químicos. Instituto Nacional de Metrologia, Normalização e Qualidade Industrial (INMETRO). DOQ-CGCRE-008 INMETRO: Brasil, 2003.

Kalbe, U, Bandow, N, Bredow, A, Mathies, H., \& Piechotta, C. (2014). Column leaching tests on soils containing less investigated organic pollutants. Journal of Geochemical Exploration, 47, 291-297.

Kalbe, U., Berger, W., Simon, F. G., Eckardt, J., \& Christoph, G. (2007). Results of interlaboratory comparisons of column percolation tests. Journal of Hazardous Materials, 148, 714-720.

Khan, M. A., \& Brown, C. D. (2016). Influence of commercial formulation on leaching of four pesticides through soil. Science of the Total Environment, 573, $1573-1579$.

Kim, H., Dong-Uk, K., Lee, H. S., Yun, J., \& Ka, J. (2017). Syntrophic biodegradation of propoxur by Pseudaminobacter sp. SP1a and Nocardioides sp. SP1b isolated from agricultural soil. International Biodeterioration \& Biodegradation, 118, 1-9.

Leistra, M., Smelt, J. H., \& Lexmond, T. M. (1976). Conversion and leaching of aldicarb in soil columns. Pesticide Science, 7, 471-482.

Lewis, K. A., Tzilivakis, J., Warner, D., \& Green, A. (2016). An international database for pesticide risk assessments and management. Human and Ecological Risk Assessment: An International Journal, 22(4), 1050-1064.

Lightfoot, E. M., Thorne, O. S., Jones, R. L., Hansen, J. L., \& Romine, R. R. (1987). Laboratory studies on mechanisms for the degradation of aldicarb, aldicarb sulfoxide and aldicarb sulfone. Environmental Toxicology and Chemistry, 6, 377-394.

Matragolo, P. F. F. R. (1999). Avaliação da percolação do triadimenol no solo por cromatografia gasosa e cromatografia líquida de alta eficiência. [Dissertação de Mestrado]. Viçosa (MG): Universidade Federal de Viçosa.

Morais, E. H. da. C., Begnini, F. R., \& Jardim, I. C. S. F. (2013). Técnicas de preparo de amostra empregadas na determinação de agrotóxicos carbamatos em água e solo. Scientia Chromatographica, 5(2), 146-162.

Nunes, G. S., \& Ribeiro, M. L. (1999). Pesticidas: legislação e controle. Pesticidas: Revista de Ecotoxicologia e Meio Ambiente. 9, $31-34$.

Palma, D. C. A., Lourencetti, C., Uecker, M. E., Mello, P. R. B., Pignati, W. A., \& Dores, E. F. G. C. (2014). Simultaneous determination of different classes of pesticides in breast milk by solid-phase dispersion and GC/ECD. Journal of the Brazilian Chemical Society, 25(8), 1419-1430.

Piffer, R. (1989). Movimento e degradação de aldicarbe e sulfona de aldicarbe em dois solos [Dissertação de Mestrado]. Lavras (MG): Escola Superior de Agricultura de Lavras.

Piffer, R., \& Rigitano, R. L. O. (1991). Lixiviação e degradação do inseticida aldicarb em dois diferentes solos. Ciência e Prática, $15,355-363$.

Rao, P. S. C., \& Jessup, R. E. (1982). Sorption and movement of pesticides and other toxic organic substances in soils. In: Nelson, D. W., Elrick, D. E., Tanji, K. K. editors. Chemical mobility and reactivity in soil systems. Soil Science Society of America Journal Madison (WI). 183-201. 
Research, Society and Development, v. 10, n. 5, e13710514824, 2021

(CC BY 4.0) | ISSN 2525-3409 | DOI: http://dx.doi.org/10.33448/rsd-v10i5.14824

Reatto, A., \& Martins, E. S. (2005). Classes de solo em relação aos controles da paisagem do bioma Cerrado. In: Scariot, A., Souza-Silva, J. C., Felfili, J. M. editors. Cerrado: ecologia, biodiversidade e conservação. Ministério do Meio Ambiente. Brasília (DF). 49-59.

Refatti, J. P., de Avila, L. A., Noldin, J. A., Pacheco, I., \& Pestana, R. R. (2017). Leaching and residual activity of imidazolinone herbicides in lowland soils. Ciência Rural, 47(5), 1-6.

Rigitano, R. L. O., Souza, J. C., \& Tonhasca, Jr, A. (1993). Ocorrência de aldicarbe em folhas do cafeeiro e seu efeito no controle do bicho-mineiro Perileucoptera coffela (Guérin-Meneville, 1842). Ciência e Prática, 17(1), 43-48.

Santaladchaiyakit, Y., Srijaranal, S., \& Burakham, R. (2012). Methodological aspects of sample preparation for the determination of carbamate residues: A review. Journal of Separation Science, 35(18), 2373-2389.

Silva, R. R. D., Silva, M. L. N., Cardoso, E. L., Moreira, F. M. de. S., Curi, N., \& Alovisi, A. M. T. (2010). Biomassa e atividade microbiana em solo sob diferentes sistemas de manejo na região fisiográfica Campos das Vertentes - MG. Revista Brasileira de Ciência do Solo, 34(5), 1584-1592.

Tankiewicz, M., Fenik, J., \& Biziuk, M. (2010). Determination of organophosphorus and organonitrogen pesticides in water samples. TrAC Trends in Analytical Chemistry, 29(9), 1050-1063.

Wauchope, D., Yeh, S., Linders, J., Kloskowski, R., Tanaka, K., Rubin, B., Katayama, A., Kordel, W., Gerstl, Z., Lane, M., \& Unsworth, J. (2002). Review: Pesticide soil sorption parameters: theory, measurement, uses, limitations and reliability. Pest Management Science, 58, 419-445.

Wilkinson, C. F., Babish, J. G., Lemley, A. T., et al. (1985). A toxicological evaluation of aldicarb and its metabolites in relation to the potential human health impact of aldicarb residues in Long Island ground water. New York: Cornell University. Committee from the Institute for Comparative and Environmental Toxicology; Unpublished report.

Xavier, F. G., Righi, D. A., \& Spinosa, H. S. (2007). Toxicologia do praguicida aldicarb (“chumbinho"): aspectos gerais, clínicos e terapêuticos em cães e gatos. Ciência Rural, 37(4), 1206-1211. 